\title{
Sensing crop nitrogen status with fluorescence indicators. A review
}

\author{
Nicolas Tremblay $\cdot$ Zhijie Wang • Zoran G. Cerovic
}

Accepted: 31 January 2011 / Published online: 6 July 2011

(C) INRA and Springer Science+Business Media B.V. 2011

\begin{abstract}
The optimization of nitrogen $(\mathrm{N})$ fertilization is the object of intense research efforts around the world. Overfertilization is commonly used as a form of insurance against uncertain soil fertility level. However, this practice results in lower nitrogen use efficiency, high levels of residual $\mathrm{N}$ after harvest, and losses in the environment. Determining an $\mathrm{N}$ recommendation that would preserve actual crop requirements, profitability of the farm, and quality of the environment has been subjected to a number of research initiatives with a variable degree of success. On one hand, soil tests are capable of estimating the intensity of $\mathrm{N}$ release at any point in time, but rarely the capacity factor over a longer period. On the other hand, in the context of in-season $\mathrm{N}$ applications, crops are often considered good integrators of factors such as the presence of mineral N, climatic conditions, soil properties, and crop management. Strategies have been proposed with plant sensor-based diagnostic information for $\mathrm{N}$ recommendations, but the sensitivity of reflectance-based parameters alone do not provide complete satisfaction (delayed
\end{abstract}

N. Tremblay $\cdot$ Z. Wang

Agriculture and Agri-Food Canada,

430 Gouin Blvd,

Saint-Jean-sur-Richelieu, Quebec, Canada J3B 3E6

Z. Wang

e-mail: wangzhijie626@hotmail.com

Z. G. Cerovic

Laboratoire Ecologie, Systématique et Évolution UMR 8079,

CNRS, Université Paris-Sud 11,

91405 Orsay Cedex, France

e-mail: zoran.cerovic@ese.u-psud.fr

N. Tremblay $(\bowtie)$

430 Gouin Blvd,

Saint-Jean-sur-Richelieu, Quebec, Canada J3B 3E6

e-mail: nicolas.tremblay@agr.gc.ca sensitivity, need of specific chlorophyll, biomass or cover fraction ranges, lack of specificity to the $\mathrm{N}$ stress). Fluorescence sensing methods have been used to monitor crop physiology for years, and they may offer solutions for $\mathrm{N}$ status diagnosis over reflectance-based methods. In this paper, we review three plant fluorescence components related to four sensing approaches-variable chlorophyll fluorescence, leaf chlorophyll content-related fluorescence emission ratio, blue-green fluorescence, and epidermal screening of chlorophyll fluorescence by phenolic compounds-from the perspective of their relevance to $\mathrm{N}$ fertilization management of agricultural crops. We examine the existence of $\mathrm{N}$-induced changes in each case, together with applications and limitations of the approach. Among these approaches, the fluorescence emission ratio method is the most important and the most widely used to date. However, blue-green fluorescence and epidermal screening of chlorophyll fluorescence by phenolic compounds has also received a great deal of attention particularly with the recent commercial release of instruments which can measure in real time and in vivo both the leaf chlorophyll content and several phenolic compounds (anthocyanins, flavonoïds, hydroxycinnamic acids). Overall, our conclusion is that fluorescence-based technologies allow for highly sensitive plant $\mathrm{N}$ status information, independently from soil interference, leaf area, or biomass status. They also allow for probing not only the chlorophyll status but also other physiological parameters known to react to $\mathrm{N}$ fertility conditions. These new parameters have the potential to provide new $\mathrm{N}$ status indicators that can be assessed remotely in a precision agriculture context.

Keywords Chlorophyll fluorescence $\cdot$ UV-excited fluorescence · Optical sensors · Nitrogen status · Precision crop management $\cdot$ Polyphenolics 


\section{Contents}

1. Introduction . . . . . . . . . . . . . . . . . 2

2. Plant fluorescence components. . . . . . . . . . . 2

2.1. Chlorophyll fluorescence. . . . . . . . . . . 3

2.1.1. Variable chlorophyll fluorescence. . . . . . . 3

2.1.2. Chlorophyll fluorescence emission ratio . . 4

2.2. Blue-green fluorescence. . . . . . . . . . . 4

2.3. Epidermal transmittance to UV light. . . . . . . . . 5

3. Fluorescence and crop N status. . . . . . . . . . . 5

3.1. Chlorophyll fluorescence. . . . . . . . . . . 5

3.1.1. N-induced changes and applications of variable ChlF. . . . . . . . . . . . . . . . 5

3.1.2. N-induced changes and applications of the ChlF emission ratio. . . . . . . . . . . 6

3.1.3. $\mathrm{N}$-induced changes and applications of suninduced ChlF. . . . . . . . . . . . . . 6

3.1.4. Limitations. . . . . . . . . . . . . . . . 6

3.2. Blue-green fluorescence. . . . . . . . . 6

3.2.1. N-induced changes and applications. . . . . 6

3.2.2. Limitations. . . . . . . . . . . . . . . 7

3.3. Epidermal transmittance of UV light. . . . . . . . .7

3.3.1. $\mathrm{N}-$ induced changes and applications. . . . . 7

3.3.2. Limitations. . . . . . . . . . . . . . . . . 8

4. Fluorescence technologies and precision $\mathrm{N}$ appli-

cations. . . . . . . . . . . . . . . . . 8

5. Conclusion. . . . . . . . . . . . . . . . . . 10

6. Acknowledgements. . . . . . . . . . . . . . 10

7. References. . . . . . . . . . . . . . . . . 10

\section{Intoduction}

Plants absorb radiation and use it in photosynthesis, but there is an excess amount of absorbed energy that must be dissipated (Lichtenthaler 1996; Norikane and Kurata 2001). On average, about $75 \%$ of visible irradiance is absorbed by leaves, but a very small fraction is converted to organic matter (Fig. 1).

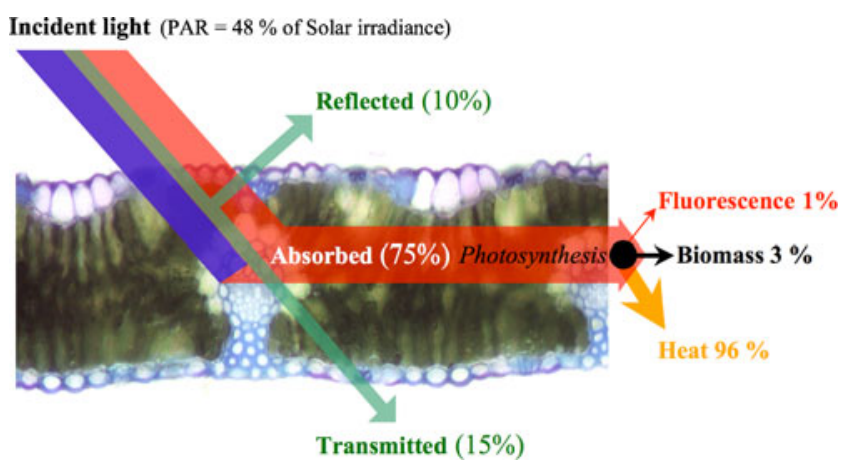

Fig. 1 Energy budget of a typical leaf. PAR photosynthetically active radiation. Indole blue-stained living section of a wheat flag leaf (courtesy of Corrado Tani and Giovanni Agati)
When a chlorophyll (Chl) molecule absorbs the energy of a given wavelength, a part of it is dissipated by light emission at longer wavelengths within a very short time. This small but variable amount of energy loss is known as the fluorescence emission. Remote sensing of plant characteristics is the evaluation of the partitioning of excitation energy between photochemistry, fluorescence, and thermal dissipation.

Plant stress modifies the relative proportions of absorbed light energy that are used for photosynthetic quantum conversion, chlorophyll fluorescence (ChlF), and heat emission. Stress also modifies the energy flow of photons through the leaf, thereby altering their absorption, reflectance and transmittance properties, and blue-green fluorescence (BGF).

Nitrogen $(\mathrm{N})$ fertilization is the object of intense research efforts around the world. The goal is not only to maintain crop productivity through $\mathrm{N}$ recommendations that will generate maximum profits for the farmer but also to protect the environment. Excess $\mathrm{N}$ fertilization of crops often leads to a reduction in net returns and groundwater contamination due to $\mathrm{NO}_{3}-\mathrm{N}$ leaching (Ferguson et al. 2002; Hashimoto et al. 2007). A balance between supply and utilization is required not only to optimize crop growth and economic returns but minimize the environmental impact as well. Samborski et al. (2009) recently reviewed the strategies available for using plant sensor-based diagnostic information for $\mathrm{N}$ recommendations. While the authors mention the existence of satellite or aircraft-based systems, the discussion centers on the most common hand-held and tractor-mounted systems. Only one fluorescence-based device, the hand-held Dualex, is discussed in their paper. The authors describe the need for further research, including work on the combined use of reflectance and fluorescence data for the estimation of plant $\mathrm{N}$ status.

Plant metabolism changes quickly (sub-seconds) or more slowly (days, week) in response to environmental changes, but the sensitivity of reflectance-based parameters alone does not provide complete satisfaction. For example, the widely used normalized difference vegetation index (Rouse et al. 1973), which is based on spectral reflectance in the near-infrared and red wavebands, is sensitive to variations in plant growth only at low levels of $\mathrm{Chl}$, low values of leaf area index, and low vegetation cover fractions (Maier and Günther 2001). Tremblay (2004) suggested that: (1) reflectance-based measurements indicate the long-term effects of stress in crop canopies, resulting in variations of $\mathrm{Chl}$ content and percent cover of green leaf biomass; (2) Chl content can be expected to change rather slowly (even more slowly than tissue $\mathrm{N}$ content, as confirmed by Tartachnyk and Rademacher 2003) in response to most environmental changes and is not affected solely by stresses; (3) fluorescence-based techniques, such as the Dualex, represent innovations in the study of $\mathrm{N}$ limitations because they do not rely on the estimation of Chl or biomass status. Canopy fluorescence emissions are associated with biophysical attributes of crop growth that could potentially 
assist in the site-specific management of variable rate $\mathrm{N}$ fertilization programs (Corp et al. 1998, 2000, 2003).

Chlorophyll fluorescence and UV-excited BGF can be used for the noninvasive detection of stress as they change long before damage of the photosynthetic apparatus is detectable (Lichtenthaler 1996; Colls and Hall 2004; Hura et al. 2006; Lenk et al. 2007; Georgieva et al. 2007). For an overview of aspects related to vegetation stress fluorescence sensing, see Lichtenthaler and Miehé (1997), Buschmann et al. 2000, and Baker and Rosenqvist (2004).

With the recent introduction of commercial devices such as the Miniveg $\mathrm{N}^{\mathrm{TM}}$, the Dualex ${ }^{\circledR}$, and the Multiplex ${ }^{\circledR}$, there is a need to review the potential and limitations of fluorescence-based techniques for crop $\mathrm{N}$ status assessment.

\section{Plant fluorescence components}

\subsection{Chlorophyll fluorescence}

\subsubsection{Variable chlorophyll fluorescence}

Chlorophyll fluorescence occurs when a photon of light with sufficiently high energy (short wavelengths) is absorbed, exciting an electron within the molecule to a higher energy state (Anderson et al. 1998). Only Chl $a$ can participate directly in the light reactions that convert solar energy to chemical energy (Lichtenthaler and Miehé 1997). This characteristic is particularly useful in the study of vegetation (Moya et al. 1992). When all photosynthetic reaction centers are ready to transfer the energy from absorbed radiation along the electron transfer chain, fluorescence is said to be quenched photochemically, which usually occurs when dark-adapted leaves are illuminated. This initial level is called $F_{\mathrm{o}}$, attesting that all photosystem II (PSII) reaction centers are open (Fig. 2). In contrast, when reaction centers are fully occupied (reduced, closed), fluorescence is no longer quenched and shows its maximum level $\left(F_{\mathrm{m}}\right)$, which is about six times higher than its initial level $\left(F_{\mathrm{o}}\right)$.

$F_{\mathrm{v}}\left(\right.$ or $\left.\mathrm{Chl}_{\mathrm{v}}\right)$ is called the "variable" fluorescence $\left(F_{\mathrm{v}}=\right.$ $F_{\mathrm{m}}-F_{\mathrm{o}}$ ), and the parameter $F_{\mathrm{v}} / F_{\mathrm{m}}$ is referred to as the photochemical efficiency of PSII (Kitajima and Butler 1975) which can reach 0.75-0.85 (Demmig-Adams and Björkman 1987; Bolhar-Nordenkampf et al. 1989; Guidi et al. 2000). It is generally accepted that high $F_{\mathrm{o}}$ indicates impeded photosynthesis and the presence of stress (Moya et al. 1992). $F_{\mathrm{m}}$ is measured under saturating irradiance when all of the reaction centers are closed (Baker and Rosenqvist 2004). The ratio $F_{\mathrm{v}} / F_{\mathrm{m}}$ provides an estimate of the maximum quantum efficiency of PSII photochemistry (Butler 1978) and has been widely used to detect stressinduced perturbations in the photosynthetic apparatus (Baker and Rosenqvist 2004). Similarly, measurement of the light-

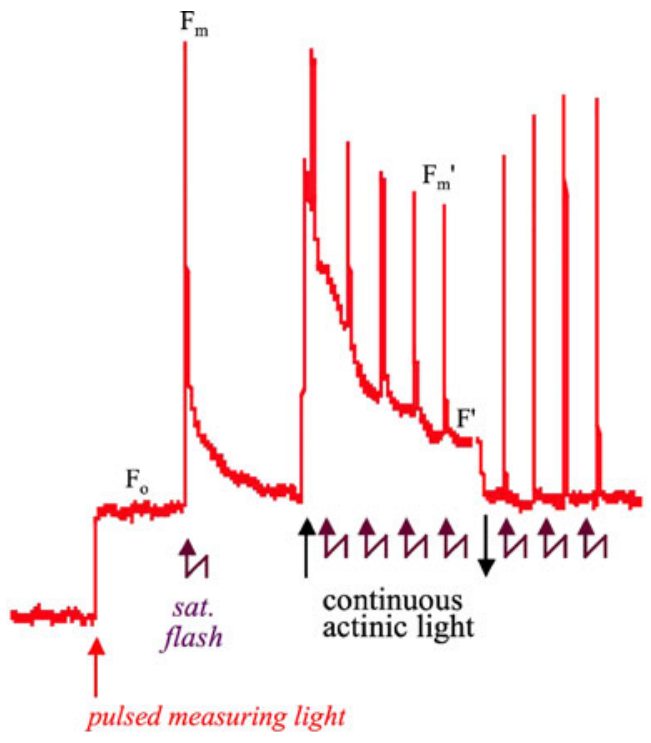

Fig. 2 Variable chlorophyll fluorescence levels

adapted fluorescence signal $\left(F^{\prime}\right)$ and the fluorescence signal when all PSII centers are closed under light-adapted conditions $\left(F_{\mathrm{m}}{ }^{\prime}\right)$ allows for the estimation of the "operating" photon efficiency of PSII photochemistry, which can be calculated as $\left(F_{\mathrm{m}}{ }^{\prime}-F^{\prime}\right) / F_{\mathrm{m}}{ }^{\prime}$ (Genty et al. 1989).

Chlorophyll fluorescence parameters $\left(F_{\mathrm{o}}, F_{\mathrm{v}} / F_{\mathrm{o}}, F_{\mathrm{v}} / F_{\mathrm{m}}\right.$, non-photochemical quenching, and photochemical quenching) are affected by water stress (Valentini et al. 1994), temperature (Hassan 2006), Chl and flavonoid contents (Lichtenthaler and Miehé 1997; Meyer et al. 2003), pH (Cregg et al. 2004), time of measurement, canopy parameters, and photosynthetic status (Méthy et al. 1994; Günther et al. 1994). The study of these parameter is called quenching analysis (Baker and Rosenqvist 2004), and the related variations of $\mathrm{Chl}$ fluorescence are referred to as variable Chl fluorescence, or Kautsky kinetics (Moya et al. 1992). This area of research on Chl fluorescence is characterized by the largest part of the published work by far. Portable ChlF instruments such as the OS-5-FL (OptiSciences, Tyngsboro, MA, USA), the LI-COR 6400R (LICOR, Lincoln, NE, USA), and the pulse amplitude modulation fluorometer (Waltz, Effeltrich, Germany) are widely used to take measurements from individual leaves for the assessment of crop health status (Schreiber and Bilger 1993; Schreiber et al. 1994; Häder et al. 1997; Zarco-Tejada et al. 2002; Adams et al. 1999; Richards et al. 2003; Tartachnyk and Rademacher (2003); Esteban et al. 2010). Nitrogen fertilization can also affect the photosynthetic apparatus and therefore affect variable Chl fluorescence. Yet, attempts to use quenching analyses for $\mathrm{N}$ status determination or other agricultural applications are seldom (e.g., Mauromicale et al. 2006; Tartachnyk et al. 2007; Xu et al. 2008) since a fixed distance of measurement is required, which cannot be accommodated in most applica- 
tions. Tartachnyk and Rademacher (2003) suggested that laser-induced fluorescence technologies producing chlorophyll fluorescence emission ratios were more conducive to remote and large-area field measurements as compared with variable chlorophyll fluorescence measurement technologies.

\subsubsection{Chlorophyll fluorescence emission ratio}

Variation of the Chl fluorescence emission ratio-F685/F730, F690/F730, or F690/F740 (red fluorescence (RF)/far-red fluorescence (FRF); Fig. 3) - associated with stresses can be attributed to either a change in photosynthesis status or a change in the $\mathrm{Chl}$ content. This ratio is sensitive to $\mathrm{Chl}$ content because of the process of re-absorption of the emitted fluorescence at $690 \mathrm{~nm}$ (Agati 1998). In practice, the RF/FRF ratio has mostly been used (Günther et al. 1994; Corp et al. 2003; Apostol et al. 2007; Buschmann 2007; Campbell et al. 2008), but it is sensitive to Chl changes only in lightly green leaves $\left(<25 \mu \mathrm{g} \mathrm{Chl} \mathrm{cm}{ }^{-2}\right.$; Moya et al. 1992; Lichtenthaler 1996; Gitelson et al. 1998).

In contrast, the use of the inverse ratio, FRF/RF, varies almost linearly with $\mathrm{Chl}$ content in the physiological range of crop leaves (20-60 $\mu \mathrm{g} \mathrm{Chl} \mathrm{cm}{ }^{-2}$; Gitelson et al. 1999; Cerovic et al. 2009), and this characteristic makes it the preferred descriptor of the relationship with $\mathrm{Chl}$ content. This parameter (renamed SFR) is offered by the recently released Multiplex instrument (Fig. 4).

Because the RF peak has a relatively high contribution to PSII emission (Moya et al. 1992), variable Chl fluorescence (cf. Section 2.1.1) will affect RF peak more than FRF peak

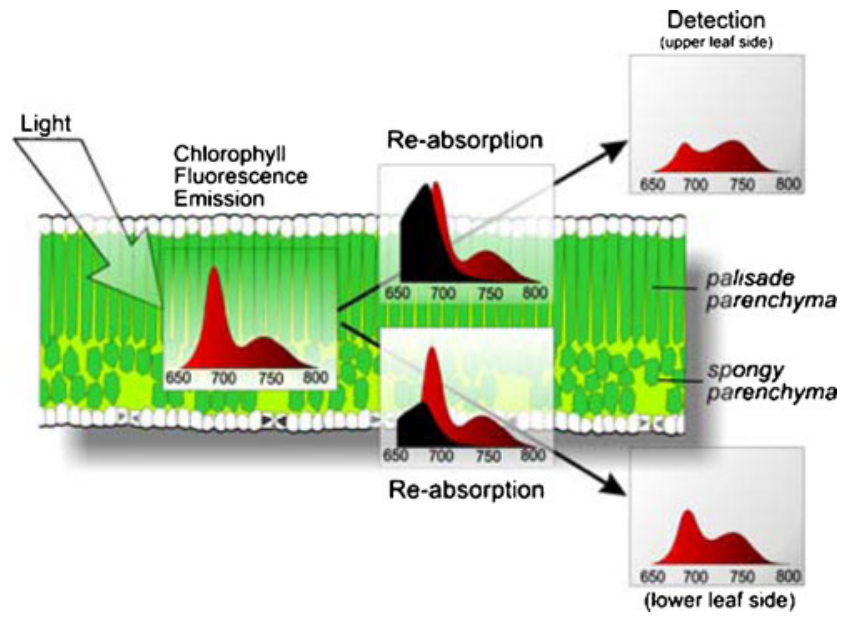

Fig. 3 Emission and detection of light-induced Chl fluorescence with a scheme indicating the re-absorption of primarily the red Chl fluorescence band by the in vivo absorption bands of Chl inside a bifacial leaf. The Chl fluorescence emission spectrum (red) overlaps with the Chl absorption spectrum (black). The re-absorption depends on the Chl density and is higher when detecting the Chl fluorescence from the upper leaf side (high Chl content in the densely packed palisade parenchyma cells) as compared with the lower leaf side (less $\mathrm{Chl}$ in the spongy parenchyma layer). With kind permission from Springer Science+Business Media: Buschmann (2007), p. 265, Fig. 3

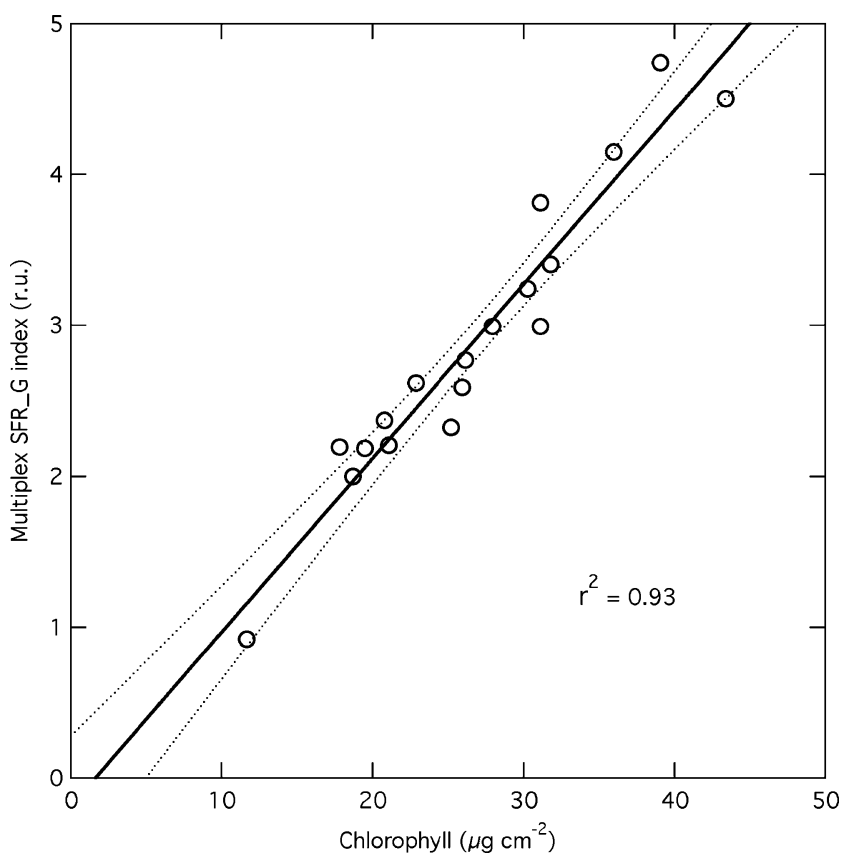

Fig. 4 Detached Kiwifruit (Actinidia deliciosa) leaves of different age measured from the adaxial side. Standard Multiplex configuration: 8-cm diameter illumination surface, $10 \mathrm{~cm}$ from the detectors, 1 -s measurements, 250 flash average. Chlorophyll estimation by extraction in $100 \%$ methanol according to Porra et al. (1989)

so that the RF/FRF ratio also provides a sensitive and noninvasive indicator of environmental stress (Buschmann 2007), but only when no significant reduction in Chl content has occurred (Campbell et al. 2008).

\subsection{Blue-green fluorescence}

Under UV excitation, leaves emit blue fluorescence (BF), green fluorescence (GF), RF, and FRF, with maxima around 450, 530, 685, and $735 \mathrm{~nm}$, respectively (Chappelle et al. 1991; Lang et al. 1992; Cerovic et al. 1999; Ounis et al. 2001; Campbell et al. 2007; Fig. 5).

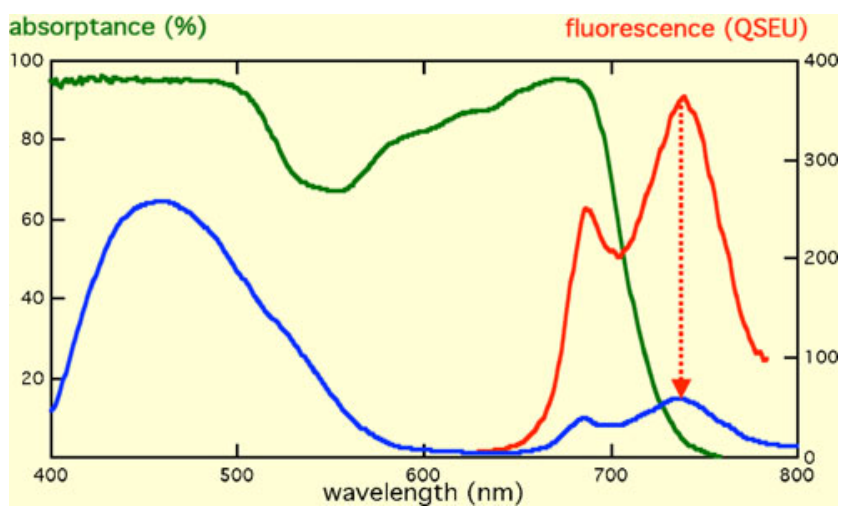

Fig. 5 Fluorescence of a leaf in the blue-green and the red-far-red region of the spectrum. The blue line represents BGF and Chl fluorescence produced by a wheat leaf submitted to a UV excitation $(355 \mathrm{~nm})$. The red line represents $\mathrm{Chl}$ fluorescence obtained under blue $(460 \mathrm{~nm})$ excitation 
The BF and GF components originate from hydroxycinnamic acids (Chappelle et al. 1991; Lang et al. 1992; Ounis et al. 2001; Meyer et al. 2003). Blue-green fluorescence is primarily emitted by two cinnamic acids, $p$-coumaric acid and ferulic acid (Lichtenthaler and Schweiger 1998; Hura et al. 2007), more specifically, "cell wall-bound" ferulic acid (Morales et al. 1994; Lichtenthaler and Schweiger 1998). Plants that do not have ferulic acid in their cell walls, such as sunflower (Helianthus annuus L.), pumpkin (Cucurbita pepo L.), and tobacco (Nicotiana tabacum L.), exhibit only very faint BGF emissions (Lichtenthaler and Schweiger 1998). Studies have also shown that pyridine nucleotides represent a minor contribution to the BGF of leaves (Lang et al. 1992; Cerovic et al. 1993). In an earlier study, Chappelle et al. (1991) suggested that NADPH was responsible for the BF at $440 \mathrm{~nm}$, but this was the result of a misinterpretation based on indirect correlations with photosynthetic activity. Cerovic et al. (1998) showed that photosynthetic pigments (Chls and carotenoids) reabsorb most of the BF emitted by chloroplast NADPH.

The BGF-emitting components are far more abundant in the epidermis than in the mesophyll, and more on the adaxial side than the abaxial side (Cerovic et al. 1994). Langsdorf et al. (2000) showed that BGF was high in the leaf veins of sugar beet (Beta vulgaris L.) plants. Subhash et al. (1999) reported that young yellowish green leaves of an aurea mutant of tobacco showed a much higher BGF emission and lower ChlF as compared with the green wild type. Blue-green fluorescence remains constant over time as long as there are no changes in pigment content or in the optics of the leaf (Buschmann et al. 2000).

\subsection{Epidermal transmittance to UV light}

Nearly all plant leaves accumulate UV-absorbing phenolic compounds (Phen) in their epidermis. Two major classes of UV-screening Phen are known: hydroxycinnamic acids, absorbing predominantly in the UV-B range (280-315 nm), and flavonoids, exhibiting a broader absorbance range including the UV-A (315-400 nm; Cockell and Knowland 1999; Cerovic et al. 2002). Close et al. (2007) reported three classes of Phen compounds (gallotannin, stilbene, and flavonol) that show similar responses to UV-A radiation. Robberecht and Caldwell (1978) found that leaf epidermal transmittance of UV radiation (280-400 $\mathrm{nm}$ ) in several plant species was generally $<10 \%$. Bilger et al. (1997) reported that sun plants showed lower ratios of $\mathrm{UV} / \mathrm{BG}$-induced $\mathrm{ChlF}$, and therefore lower epidermal UV transmittance than shade plants, presumably due to greater UV-screening capacities. Krause et al. (2003) reported that in most cases, UV-A shielding by the abaxial epidermis was lower than shielding by the adaxial epidermis. This is due to the preferential accumulation of flavonols in the adaxial epidermis (Bidel et al. 2007; Fig. 6). Measurements of in vivo $\mathrm{ChlF}$ indicated that the ratio of UV-absorbing screening pigments per leaf area increased in monocots from the leaf base to the tip (Wagner et al. 2003; Meyer et al. 2003).

Ultraviolet absorbance of the leaf extracts of tropical forest plants is generally higher in sun leaves than in shade leaves, and the absorbance is much higher in the UV-B spectral region at $305 \mathrm{~nm}$ than in the UV-A region at $375 \mathrm{~nm}$ (Krause et al. 2003). Stober et al. (1994) reported that plants grown in the field at a high photon flux density showed higher F450/F690 values, primarily caused by a greatly reduced penetration depth of the exciting UV light into the leaf attributable to absorbing substances in the epidermal layers. Nybakken et al. (2004) found that artificially increased UV-B radiation and temperature did not consistently influence epidermal UV-B transmittance in a group of vascular plant species, which suggests that environmental factors other than UV-B radiation may influence epidermal UV-B screening. In monocots, the basal leaf segments that are in the early stage of development are less protected against UV radiation than fully developed mature leaf regions (Wagner et al. 2003). This can even be exploited to characterize leaf developmental stage (Meyer et al. 2003).

\section{Fluorescence and crop $\mathbf{N}$ status}

\subsection{Chlorophyll fluorescence}

\subsubsection{N-induced changes and applications of variable ChlF}

In a study analyzing the effect of $\mathrm{N}$ on ChlFv, Lima et al. (1999) concluded that regardless of external $\mathrm{P}$ supply, $F_{\mathrm{v}} / F_{\mathrm{m}}$ decreased by about $7 \%$ and $F_{\mathrm{v}} / F_{\mathrm{o}}$ by $25 \%$ in low-N-content plants of bean (Phaseolus vulgaris L.). Huang et al. (2004)
Fig. 6 Differential screening characteristic of a leaf to UV and red light due to flavonoid accumulation in the adaxial epidermis

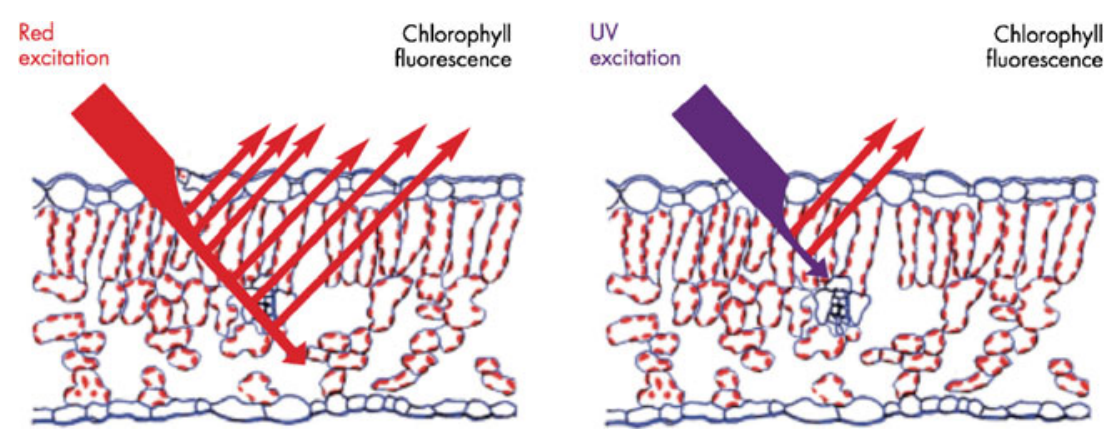


reported that there was a higher non-photochemical quenching in $\mathrm{N}$-stressed rice (Oryza sativa L.) plants. As $\mathrm{N}$ deficiency was maintained, $F_{\mathrm{v}} / F_{\mathrm{m}}, F_{\mathrm{v}}{ }^{\prime} / F_{\mathrm{m}}{ }^{\prime}$ (variable/maximum fluorescence during a saturating light flash; DemmigAdams et al. 1989), and photochemical quenching were lowered more rapidly in $\mathrm{N}$-deficient than in non-deficient plants. These findings are consistent with those reported by Khamis et al. (1990) for corn (Zea mays L.) plants. N deficiency may affect PSII photochemistry because $\mathrm{N}$ deficiency decreases the quantum yield of PSII electron transport and $F_{\mathrm{v}} / F_{\mathrm{m}}$ (Lu and Zhang 2000; DaMatta et al. 2002). $\mathrm{NH}_{4}{ }^{+}$additions produced more complex effects on fluorescence than $\mathrm{NO}_{3}{ }^{-}$additions (Shelly et al. 2007).

\subsubsection{N-induced changes and applications of the ChlF emission ratio}

Chlorophyll fluorescence emission ratio has now been widely applied to crop N status monitoring. Thanks to the development of specific instruments (cf. Section 4), ChlF has been used to assess $\mathrm{N}$ supply, uptake, and biomass under field conditions (Langsdorf et al. 2000; Bredemeier and Schmidhalter 2003; Mauromicale et al. 2006). Thoren and Schmidhalter (2009) reported that $\mathrm{N}$ status and aerial biomass dry weight can be determined simultaneously by laser-induced two-wavelength $\mathrm{Chl}$ fluorescence measurements with accuracy comparable to conventional methods. Furthermore, the soil does not influence the measured fluorescence signal. This method measures the $\mathrm{Chl}$ fluorescence induced by red laser light at $630 \mathrm{~nm}$. The ratio of the 690- and 730-nm fluorescence wavelengths correlates strongly with aboveground $\mathrm{N}$ content, with statistical analysis of measurement data providing biomass information (Lejealle et al. 2010; Zhang and Tremblay 2010).

\subsubsection{N-induced changes and applications of sun-induced ChlF}

Sun-induced fluorescence is potentially the best indicator of absorbed photosynthetically active radiation, the most important parameter defining plant productivity (Cerovic et al. 1995; Maier and Günther 2001). However, quantifying the amount of ChlF emitted by a leaf or a canopy under natural sunlight is difficult because the reflected light overwhelms the fluorescence signal. Sun-induced fluorescence (Maier and Günther 2001; Meroni et al. 2010) has been estimated from airborne data (Zarco-Tejada et al. 2009). The 4th International Workshop on Remote Sensing of Vegetation Fluorescence (Valencia, Spain, November 2010) has revealed the current status of this research area (http://www.congrex.nl/10c23/). So far, very little of this new application opportunity has addressed the issue of $\mathrm{N}$ status assessment. Only contributions from the NASA group (Diurnal and Directional Responses of Chlorophyll Fluores- cence and the PRI in a Cornfield, by E. Middleton, Y.-B. Cheng, L. Corp, P. Campbell, W. Kustas) reported preliminary results on the $\mathrm{R} / \mathrm{FR}$ as it related to $\mathrm{N}$ pretreatments of corn stands, but in a somewhat inconsistent manner.

\subsubsection{Limitations}

So far, ChlFv has not been widely used to obtain field measurements of $\mathrm{N}$ status. Most commercially available fluorometers proceed from measurements on individual leaves, and screening large numbers of plants is time-consuming (Baker and Rosenqvist 2004). The major limitation for the use of ChlF emission ratio is the larger variations of $\mathrm{ChlFv}$ in the RF than in the FRF emission band. Furthermore, some fluorescence parameters, such as F690/F730 and F740/F685, are not very sensitive either to the leaf area and structure of the vegetation or to Chl content (Méthy et al. 1991; Takeuchi et al. 2002). Field measurements of laser-induced two-wavelength $\mathrm{Chl}$ fluorescence under variable light conditions showed a linear influence of direct sunlight on the ratio of F690/F730, whereas the ratio was unchanged under diffuse sunlight (Thoren et al. 2010). $F_{\mathrm{v}} / F_{\mathrm{m}}$ is not considered a robust indicator of nutrient status or relative growth rate (Rodríguez-Román and Iglesias-Prieto 2005; Kruskopf and Flynn 2006).

\subsection{Blue-green fluorescence}

\subsubsection{N-induced changes and applications}

Blue-green fluorescence has been shown to be influenced by the nutrient content in soil (Chappelle et al. 1991). Mercure et al. (2004) stated that the increase in barley (Hordeum vulgare L.) leaf Phen compounds observed with limiting N supply was accompanied by large increases of BGF intensity and the BGF/ChlF(UV) ratio of leaf sections. Langsdorf et al. (2000) demonstrated that BGF of sugar beet plants increased at higher $\mathrm{N}$ application rates. A similar trend was reported by Heisel et al. (1997) for wheat (Triticum aestivum L.), but Campbell et al. (2007) found that BGF decreases in corn with $\mathrm{N}$ at high $\mathrm{N}$ application rates. For most species and conditions, $F(\mathrm{UV}-\mathrm{B}) / F(\mathrm{BG})$ ratios are higher for abaxial than adaxial leaf surfaces (Barnes et al. 2000).

Blue-green fluorescence has been used in conjunction with ChlF to detect plant stress and identify plant types (Chappelle and Williams 1987; Chappelle et al. 1991). Remote sensing of $\mathrm{BF}$ appears to be a suitable technique for determining the state of health of terrestrial vegetation (Stober et al. 1994). Images of the fluorescence ratios BF/RF (F440/F690) and BF/FRF (F440/F740) are early stress indicators (Buschmann et al. 2000) and are more sensitive to growth conditions than F690/F740 (Heisel et al. 1996). These two ratios have been used to distinguish sugar beet plants with high $\mathrm{N}$ supply from those with low N supply (Langsdorf et al. 2000). 


\subsubsection{Limitations}

GF emission intensities excited at $404 \mathrm{~nm}$ sometimes were too low to be used (Schweiger et al. 1996). Richards et al. (2003) reported that BF/GF ratios for both bean and wheat plants were insensitive to rapid changes in light levels. Because of the Phen origin of BGF, it is strongly dependent on temperature, like any fluorophore in vitro (Bongi et al. 1994; unlike Chl which is linked to proteins). BGF emission therefore strongly depends on environmental factors experienced by the plant (Chappelle et al. 1984). Leaf BGF increased when leaf temperature decreased $(5 \%$ of BGF change per degree Celsius), while RF remained unchanged (Bongi et al. 1994; Morales et al. 1998). Therefore, BGF is not a good parameter to use for plant physiological characteristics assessment when temperature is variable. When the temperature does not change during the measurement of the BGF/FRF_UV ratio, the latter is mostly influenced by the decrease in FRF_UV due to the screening by epidermal Phen.

\subsection{Epidermal transmittance of UV light}

\subsubsection{N-induced changes and applications}

The value of leaf UV absorbance is directly correlated with the amount of Phen (Cockell and Knowland 1999; Cerovic et al. 2002). Polyphenolics are mainly present in leaf epidermis and they have typical UV absorption peaks in the UV-A and UV-B (Cerovic et al. 2002). When $\mathrm{N}$ is limiting for plant growth, the carbon/nutrient balance hypothesis (Bryant et al. 1983) predicts that carbohydrates will accumulate in plant tissues. The increased content of carbohydrates will lead to increased synthesis of carbon-based secondary metabolites such as Phen and terpenes (Hamilton et al. 2001). An increase in leaf Phen contents has been linked to $\mathrm{N}$ deficiency (Cartelat et al. 2005; Tremblay et al. 2007). Lea et al. (2007) showed that $\mathrm{N}$ deficiency results in the accumulation of some Phen compounds, such as anthocyanins and flavonols, and in enhanced transcript levels of certain genes important for the accumulation of anthocyanins and flavonols.

Ounis et al. (2001) showed that the epidermal UV absorption of vegetation can be estimated from the ChlF excitation ratio, $\Phi F(532) / \Phi F(355)$. Bilger et al. (1997) and Barnes et al. (2000) reported that noninvasive estimates of epidermal transmittance of UV radiation using ChlF can detect changes in pigmentation and in leaf optical properties induced by UV-B radiation under both field and laboratory conditions. Samson et al. (2000) found that Phen may be a more specific indicator of crop $\mathrm{N}$ status than Chl because the latter is sensitive to sulfur deficiency. Bengtsson et al. (2006) stated that ChlF can be used to estimate the content of flavonoids in broccoli (Brassica oleracea L.) flower buds by measuring the relative epidermal absorbance of blue light.

Leaf fluorescence emissions significantly increase with $\mathrm{N}$ fertilization, reach a plateau (or maximum) for optimal rates, and decline slightly at high $\mathrm{N}$ rates (Corp et al. 2003). These changes in UV-induced FRF can be explained by the accumulation of Phen in the epidermis under $\mathrm{N}$ deficiency (Cartelat et al. 2005).

The aforementioned screening of Chl by Phen was used in a commercial leaf clip called Dualex ${ }^{\circledR}$. This instrument measures UV (375 nm) absorption of the leaf epidermis by the double excitation of ChlF in relation to $\mathrm{N}$ availability (Fig. 7). The UV/Visible fluorescence excitation ratio has been described as the most sensitive and consistent parameter in discriminating $\mathrm{N}$ treatments (Apostol et al. 2007). The Dualex has been used to assess $\mathrm{N}$ status in both wheat and corn (Cartelat et al. 2005; Cerovic et al. 2005; Tremblay et al. 2007; 2010). Dualex was found to have potential for predicting wheat grain protein content (Cerovic et al. 2005).

Multiplex ${ }^{\circledR}$ is the latest hand-held optical fluorescence sensor introduced for the non-destructive measurement of various parameters representative of plant physiological status. The instrument generates fluorescence in the plant tissues using light sources (LED) generating four wavelengths: UV_A (375 nm, UV); blue (450 nm, B); green (530 nm, G); and red $(630 \mathrm{~nm}, \mathrm{R})$. Three filtered synchronized detectors record the fluorescence in the following bands: blue-green (447 nm, BGF) when B excitation is not used or yellow $(590 \mathrm{~nm})$ when B excitation is used; red (665 nm, RF) and far-red (735 nm, FRF; Fig. 8). The combinations of these excitation and fluorescence signals result in 66 fluorescence ratios potentially useful to interpret the Chl, flavonoid, and $\mathrm{N}$ content status of plant

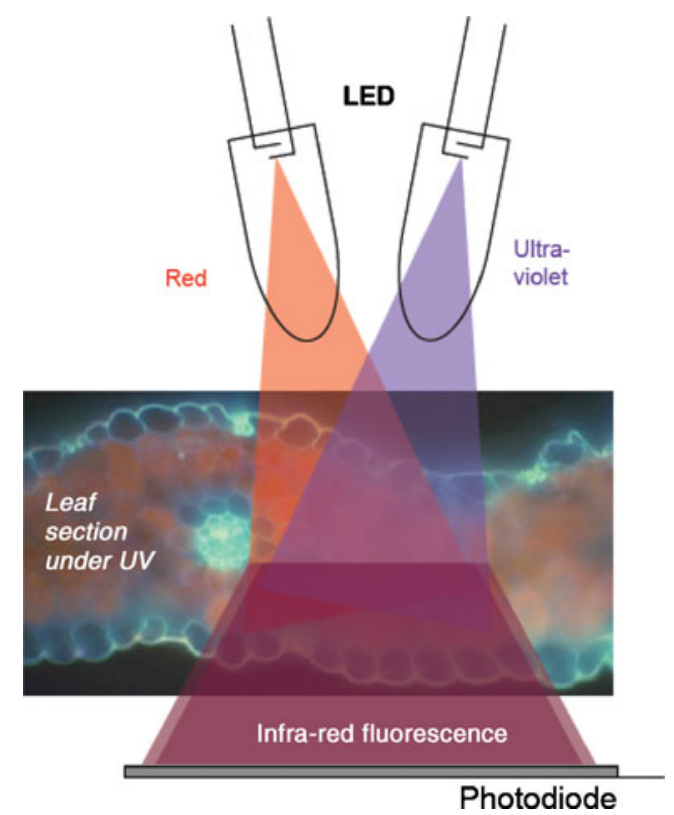

Fig. 7 Leaf UV epidermal screening estimation. Dualex principle of operation 


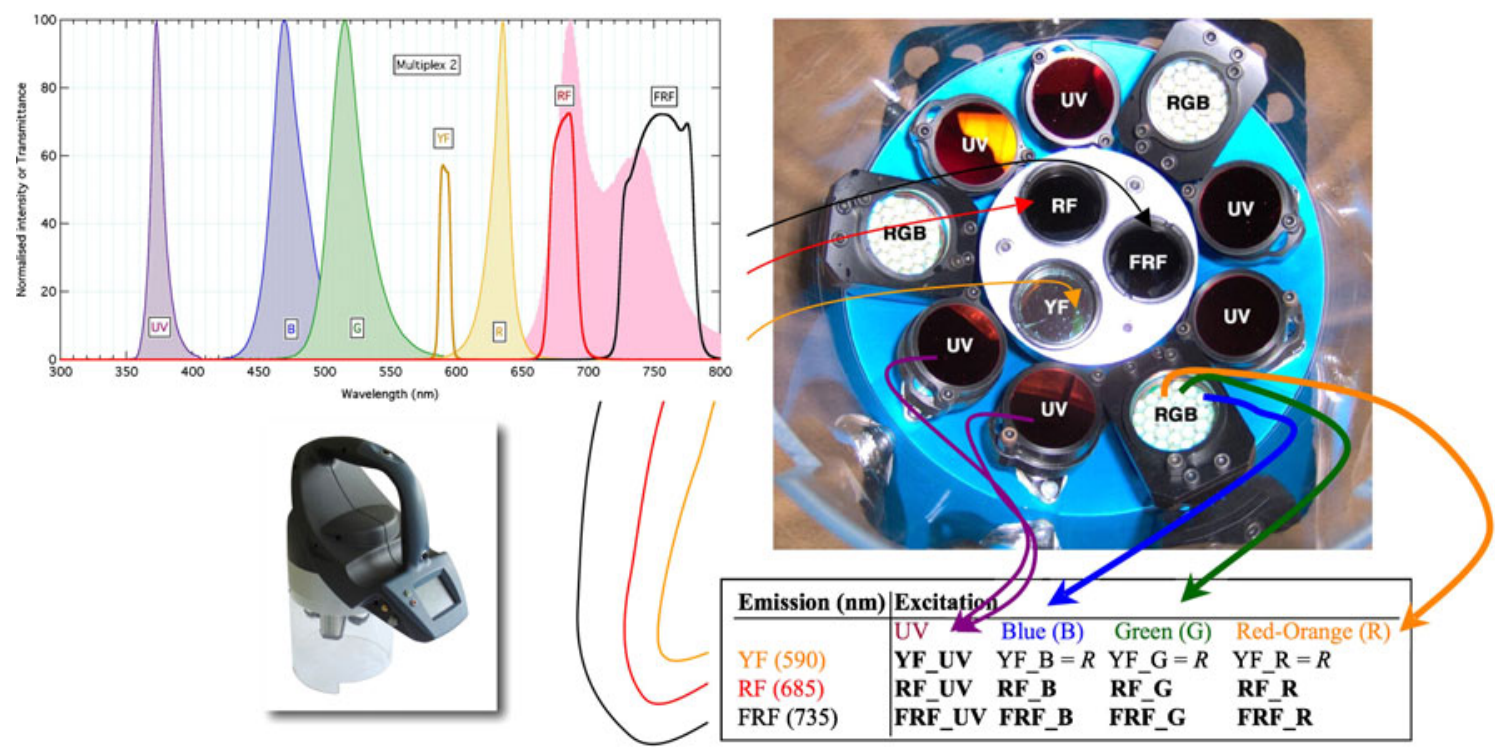

Fig. 8 Configuration of the Multiplex instrument in terms of excitation and fluorescence detection wavebands

material. Ratios are preferred over independent signals for their reduced dependency on measurement distance.

Multiplex has potential for in-season assessment of crop $\mathrm{N}$ status (Lejealle et al. 2010; Zhang and Tremblay 2010) particularly through the following indices: the Chl index (SFR_R or SFR_G under red or green excitation, respectively), the flavonoid index (FLAV), the nitrogen balance index (NBI), the transformed single-fluorescence excitation anthocyanin relative index (FERARI), and the anthocyanins content index (ANTH). SFR is defined as the simple fluorescence emission ratio FRF_R/RF_R (FRF and RF, respectively, under red excitation). FLAV is defined as log (FRF_R/FRF_UV) (FRF under red and UV excitations, respectively). NBI is the Chl-to-flavonoids ratio computed by the ratio FRF_UV/RF_R (FRF under UV excitation and $\mathrm{RF}$ under red excitation). ANTH is computed as the $\log$ (FRF-R/FRF-G) under red and green excitations. The measurement is made from a $10-\mathrm{cm}$ distance from the light sources, and the measurement surface corresponds to a circle $8 \mathrm{~cm}$ in diameter. This may be seen as a limitation particularly in high-throughput systems mounted on carriers where uneven heights in crop stands would call for the device to occasionally touch the leaf, or for sophisticated guiding system. However, a new version of the instrument is being developed that will be able to work from a 20 - to $30-\mathrm{cm}$ distance and with a larger depth of view.

\subsubsection{Limitations}

Andersen and Kasperbauer (1971) and Barnes et al. (2000) stated that ChlF was of limited utility for the noninvasive determination of the epidermal UV transmittance of plants in cold environments because UV and low temperatures can stimulate the production of BG-absorbing pigments that interfere with these indirect measurements of UV transmittance when blue light is used as a reference. This problem is alleviated by using red reference light (Pfündel et al. 2007). In green leaves, epidermal screening of UV radiation works only when the $\mathrm{Chl}$ is situated in a layer below the epidermal cell layer in which the flavonoids are located (Bengtsson et al. 2006). Nevertheless, as shown on grape berries (Agati et al. 2007), the screening effect can still be used even when there is overlap between $\mathrm{Chl}$ and a flavonoid absorber. In that case, the absorber was anthocyanin and the method was extended also to the screening of visible (green) light by anthocyanins (Ben Ghozlen et al. 2010).

Although not yet adapted for agricultural applications, the potential of fluorescence imaging of crops has also been analyzed. Corp et al. (2003) stated that a fluorescence imaging system and a laser-induced fluorescence imaging system may assist growers in site-specific management of variable rate $\mathrm{N}$ fertilization in corn. However, the flashlamp imaging system, which images red and far-red Chl fluorescence as well as BGF, has much broader potential for use in photosynthesis and ecophysiology research and in plant stress detection (Lichtenthaler et al. 2005).

\section{Fluorescence technologies and precision $\mathrm{N}$ applications}

Map- and sensor-based approaches are basic methods of implementing site-specific management for the variable rate application of crop inputs (Bredemeier and Schmidhalter 2003). With the availability of high-quality portable instruments, non-destructive measurements of ChlF can be made 
in the field (Blaikie and Chacko 1998), but most fluorescence sensors cannot be used like other on-the-go remote sensors, such as the Yara N Sensor (Yara International ASA, Dülmen, Germany), the GreenSeeker ${ }^{\mathrm{TM}}$ RT 200 (NTech Industries Inc., Ukiah, USA), or the Crop Circle ACS-430 Active Crop Canopy Sensor (Holland Scientific, Lincoln, USA). These reflectance-based sensors can be mounted on a tractor and provide information permitting real-time variable rate $\mathrm{N}$ application. Time-consuming "dark adaptation" of the plant tissue must be done for quenching analysis (Norikane et al. 2003) and is therefore incompatible with on-the-go sensing. The alternative is to use ChlF emission ratios. Planto $\mathrm{GmbH}$ (Leipzig, Germany) has developed a tractor-mounted fluorescence sensor. This sensor can reliably detect $\mathrm{N}$ uptake and biomass in wheat and corn fields with a sensed area of 6-7 $\mathrm{m}^{2}$ (Bredemeier and Schmidhalter 2003). Reflectance and fluorescence methods are sensitive in detecting corn $\mathrm{N}$ needs and may be especially powerful in monitoring crop conditions if both types of information can be combined (McMurtrey et al. 2003). The on-the-go information obtained can be coupled with a fertilization algorithm to control the amount of N fertilizer applied (Bredemeier and Schmidhalter 2003). Measurement of leaf ChlF may serve as a pre-visual, early warning indicator of crop N stress (Buschmann et al. 2000). Apostol et al. (2003) demonstrated that fluorescence can discriminate between $\mathrm{N}$-deficient and $\mathrm{N}$-sufficient corn plants. Bélanger et al. (2005) reported that $\mathrm{N}$ variables in potato (Solanum tuberosum L.) can be detected using ground-based fluorescence; almost $70 \%$ of the N-deficient plants and more than $90 \%$ of the $\mathrm{N}$-sufficient plants were correctly discriminated. Schächtl et al. (2005) reported that laser-induced fluorescence measurements can be used to estimate the $\mathrm{N}$ supply in the wheat canopy and make $\mathrm{N}$ recommendations. In general, fluorescence technologies are not used much in precision $\mathrm{N}$ management given the limitations on the measurement of fluorescence parameters under natural conditions. Fluorescence, as compared with reflectance, eliminates erroneous signals from bare soil, making it more suitable for early growth stages and for widely spaced crops (Heege et al. 2008).

Nowadays, fluorescence-based commercial instruments are available for assessing plant status. Unlike reflectancebased tools, they use approaches that enable $\mathrm{N}$ status to be estimated independently from biomass (Thoren and Schmidhalter 2009). Laser-induced fluorescence has also been proposed as a method for discriminating between $\mathrm{N}$ deficient and pathogen-infected winter wheat plants under field conditions (Tartachnyk et al. 2006).

Chlorophyll content increases whereas flavonoids content decreases with increased $\mathrm{N}$ application so that NBI increases with $\mathrm{N}$ fertility (Fig. 9). The Multiplex is a diagnostic tool that can be used to help $\mathrm{N}$ fertilization management remotely and in real time. NBI measured by Multiplex was better correlated with turfgrass leaf $\mathrm{N}$ content than Chl content alone (Lejealle et al. 2010). The NBI ratio has been used to map turfgrass $\mathrm{N}$ status of a soccer field in time and space. In corn, with the Multiplex, FERARI, ANTH, and FLAV were found to be a particularly sensitive and consistent indicator of $\mathrm{N}$ fertility conditions among sampling dates (Zhang and Tremblay 2010). Unlike the chlorophyllmeter, the Multiplex was able to distinguish $\mathrm{N}$ treatments equally well in shadow or full sunlight, and at any time during the day.

UV-induced fluorescence can be related to specific variables such as $\mathrm{N}$ deficiency and eventually calibrated to provide quantitative recommendations. Under the spectral fluorescent signature principle (or total luminescent spectroscopy (TLS): Dudelzak et al. 1991; Poryvkina et al. 1997), a matrix of fluorescent intensity resulting from several excitation and emission wavelengths is recorded. Total luminescence spectroscopy signatures are represented using 3D graphics with excitation wavelengths on the $y$-axis and fluorescence wavelengths on the $x$-axis. A comprehensive library of signatures is developed out, including both "normal" and "abnormal" cases, which are eventually linked
Fig. 9 Relationship of Phen and Chl (left) and of the Chl/Phen ratio (also called NBI, right) with leaf $\mathrm{N}$ content for wheat
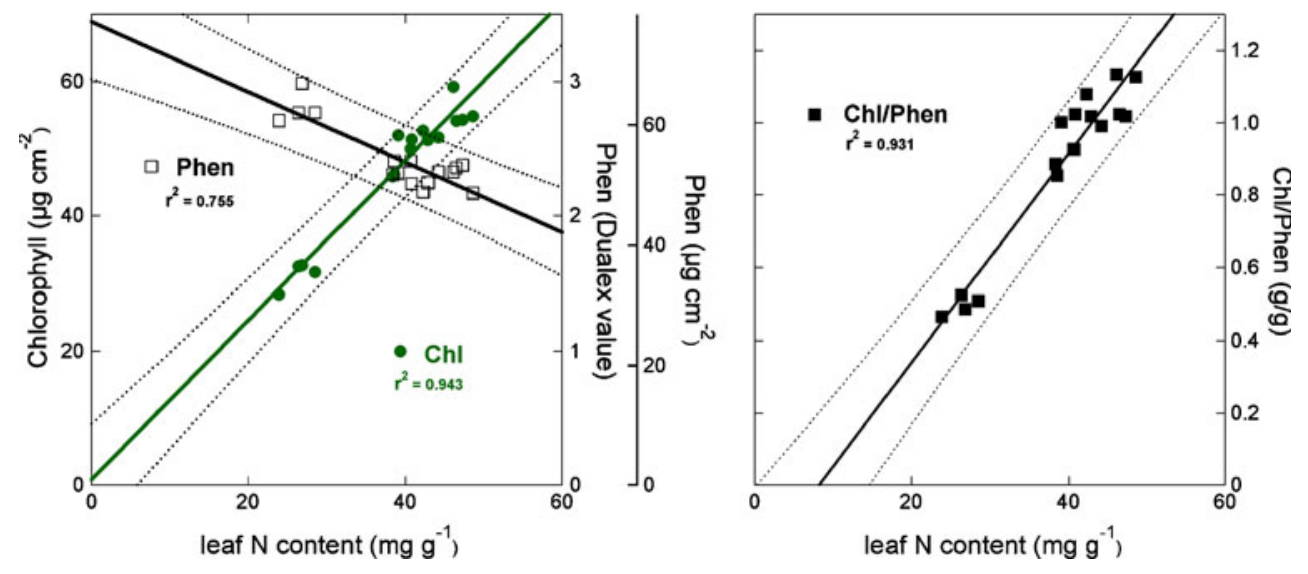
to a number of typical causes. The potential of this approach for plant canopies has not yet been assessed, but it appears to hold promise. For example, the 12 signals of the Multiplex could be analyzed using TLS.

Cartelat et al. (2005) have shown that Phen content, especially associated with $\mathrm{Chl}$ content, is an indicator of wheat $\mathrm{N}$ status. Tremblay et al. $(2007,2010)$ reported that the $\mathrm{Chl} / \mathrm{Phen}$ ratio was strongly related to the applied dose of $\mathrm{N}$; they found it to be the most sensitive and robust of several indicators throughout the season, for both corn (2007) and wheat (2010). While this $\mathrm{Chl} / \mathrm{Phen}$ ratio was obtained from combining the measurements of two instruments (a Chl meter and the Dualex 3), it now can be provided by the new Dualex 4 (where it has been relabelled as NBI) in a single operation. Similarly, Multiplex and GreenSeeker devices were recently coupled with a RTK dGPS on a tractor to define variation patterns in vine vigor (Debuisson et al. 2010). These examples of synergy between conventional and fluorescence-based approaches point to the potential of combining such methods in order to obtain a more accurate assessment of crop $\mathrm{N}$ status.

\section{Conclusion}

In this paper, the characteristics and applications of four fluorescence sensing approaches-variable chlorophyll fluorescence, leaf chlorophyll content-related fluorescence emission ratio, blue-green fluorescence, and epidermal screening of chlorophyll fluorescence by phenolic compounds - are reviewed from the perspective of crop $\mathrm{N}$ status diagnosis. Among all fluorescence techniques, the most important and most exploited signal to date is chlorophyll fluorescence. However, UV-excited blue-green fluorescence has also received a great deal of attention particularly with the recent commercial release of instruments. The use of fluorescence technique in agriculture has still been very limited because fluorescence parameters are undetectable from airborne or mobile platforms. Several studies have shown the considerable potential of combining fluorosensing and multispectral or hyperspectral remote sensing to detect plant nutrient deficiencies (Heisel et al. 1996; Cerovic et al. 1999; Apostol et al. 2003; McMurtrey et al. 2003; Campbell et al. 2007). The combined use of UV-induced fluorescence and hyperspectral imaging has already shown promise for in-field detection of plant stresses (Moshou et al. 2006; Lenk et al. 2007; Chaerle et al. 2007). For the separation of a wide range of $\mathrm{N}$ condition levels, hyperspectral $(5-10 \mathrm{~nm})$ reflectance indices were found superior as compared with fluorescence or broadband reflectance indices, but they were not able, unlike fluorescence indices, to identify unstressed vegetation conditions (Campbell et al. 2007). Should the interest be confirmed and the price of the fluorescence-based devices go down, this family of instruments may well constitute a breakthrough in the assessment of crop $\mathrm{N}$ fertilization requirements, in line with a better management of this critical and environmentally sensitive production factor. Indeed, fluorescence technology will bring new information that could couple with reflectance remote sensing. The on-the-go information obtained can be valued within a fertilizing algorithm to control the amount of $\mathrm{N}$ fertilizer. In the future, the crop diagnosis arsenal will be enriched if this kind of on-the-go sensor system is developed.

Acknowledgments The first author would like to thank Drs. Alexander Dudelzak and Sergei Babichenko for their guidance, as well as Drs. Giovanna Cecchi, Valentina Raimondi, and Giovanni Agati for hosting his OECD fellowship and the late Dr. Jürgen Wollring for his support. Z.G.C. contribution for this paper was supported by the CNRS.

\section{References}

Adams WW III, Demmig-Adams B, Logan BA, Barker DH, Osmond CB (1999) Rapid changes in xanthophyll cycle-dependent energy dissipation and photosystem II efficiency in two vines, Stephania japonica and Smilax australis, growing in the under-storey of an open eucalyptus forest. Plant Cell Environ 22:125-136. doi:10.1046/j.1365-3040.1999.00369.x

Agati G (1998) Response of the in vivo chlorophyll fluorescence spectrum to environmental factors and laser excitation wavelength. Pure Appl Opt Opt 7(4):797-807. doi:10.1088/0963-9659/7/4/016

Agati G, Meyer S, Matteini P, Zoran G (2007) Cerovic. Assessment of anthocyanins in grape (Vitis vinifera L.) berries using a noninvasive chlorophyll fluorescence method. J Agric Food Chem 55(4):1053-1061. doi:10.1021/jf062956k

Andersen RA, Kasperbauer MJ (1971) Effects of near-ultraviolet radiation and temperature on soluble phenols in Nicotiana tabacum. Phytochemistry 10:1229-1232. doi:10.1016/S0031-9422(00) 84322-8

Anderson DM, Fredrickson EL, Nachman P, Estall RE, Havstad KM, Murray LW (1998) Laser-induced fluorescence (LIF) spectra of herbaceous and woody pre- and post-digested plant material. Anim Feed Sci Technol 70:315-337. doi:10.1016/S0377-8401 (97)00088-6

Apostol S, Viau AA, Tremblay N, Briantais JM, Prasher S, Parent LE, Moya I (2003) Laser-induced fluorescence signatures as a tool for remote monitoring of water and nitrogen stresses in plants. Can J Remote Sens 29(1):57-65

Apostol S, Viau AA, Tremblay N (2007) A comparison of multiwavelength laser-induced fluorescence parameters for the remote sensing of nitrogen stress in field cultivated corn. Can J Remote Sens 33(3):150-161

Baker NR, Rosenqvist E (2004) Applications of chlorophyll fluorescence can improve crop production strategies: an examination of future possibilities. J Exp Bot 55(403):1607-1621. doi:10.1093/jxb/erh196

Barnes PW, Searles PS, Ballaré CL, Ryel RJ, Caldwell MM (2000) Noninvasive measurements of leaf epidermal transmittance of UV radiation using chlorophyll fluorescence: field and laboratory studies. Physiol Plant 109:274-283. doi:10.1034/j.1399-3054.2000.100308.x

Bélanger MC, Viau AA, Samson G, Chamberland M (2005) Determination of a multivariate indicator of nitrogen imbalance 
(MINI) in potato using reflectance and fluorescence spectroscopy. Agron J 97:1515-1523. doi:10.2134/agronj2005.0040

Ben Ghozlen N, Cerovic ZG, Germain C, Toutain S, Latouche G (2010) Non-destructive optical monitoring of grape maturation by proximal sensing. Sensors 10(11):10040-10068. doi:10.3390/ s101110040

Bengtsson GB, Schöner R, Lombardo E, Schöner J, Borge GIA, Bilger W (2006) Chlorophyll fluorescence for non-destructive measurement of flavonoids in broccoli. Postharvest Biol Technol 39:291-298. doi:10.1016/j.postharvbio.2005.11.003

Bidel LPR, Meyer S, Goulas Y, Cadot Y, Cerovic ZG (2007) Responses of epidermal phenolic compounds to light acclimation: in vivo qualitative and quantitative assessment using chlorophyll fluorescence excitation spectra in leaves of three ligneous species. J Photochem Photobiol B 88:163-179. doi:10.1016/j.jphotobiol.2007.06.002

Bilger W, Veit M, Schreiber L, Schreiber U (1997) Measurement of leaf epidermal transmittance of UV radiation by chlorophyll fluorescence. Physiol Plant 101:754-763. doi:10.1111/j.1399-3054.1997. tb01060.x

Blaikie SJ, Chacko EK (1998) Sap flow, leaf gas exchange and chlorophyll fluorescence of container-grown cashew (Anacardium occidentale L.) trees subjected to repeated cycles of soil drying. Aust J Exp Agric 38:305-311. doi:10.1071/EA97124

Bolhar-Nordenkampf HR, Long SP, Baker NR, Öquist G, Schreiber U, Lechner EG (1989) Chlorophyll fluorescence as a probe of the photosynthetic competence of leaves in the field: a review of current instrumentation. Funct Ecol 3:497-514

Bongi G, Palliotti A, Rocchi P, Moya I, Goulas Y (1994) Spectral characteristics and a possible topological assignment of blue green fluorescence excited by UV laser on leaves of unrelated species. Remote Sens Environ 47:55-64. doi:10.1016/0034-4257 (94)90128-7

Bredemeier C, Schmidhalter U (2003) Non-contacting chlorophyll fluorescence sensing for site-specific nitrogen fertilization in wheat and maize. In: Stafford J, Werner A (eds) Precision agriculture: Papers from the 4th European Conference on Precision Agriculture, Berlin, Germany, pp 103-108

Bryant JP, Chapin FS, Klein DR (1983) Carbon/nutrient balance of boreal plants in relation to vertebrate herbivory. Oikos 40:357368. doi: $10.2307 / 3544308$

Buschmann C (2007) Variability and application of the chlorophyll fluorescence emission ratio red/far-red of leaves. Photosynth Res 92:261-271. doi:10.1007/s11120-007-9187-8

Buschmann C, Langsdorf G, Lichtenthaler HK (2000) Imaging of the blue, green, and red fluorescence emission of plants: an overview. Photosynthetica 38(4):483-491

Butler WL (1978) Energy distribution in the photochemical apparatus of photosynthesis. Annu Rev Plant Physiol 29:345-378

Campbell PKE, Middleton EM, McMurtrey JE, Corp LA, Chappelle EW (2007) Assessment of vegetation stress using reflectance or fluorescence measurements. J Environ Qual 36:832-845. doi:10.2134/jeq2005.0396

Campbell EPK, Middleton EM, Corp LA, Kim MS (2008) Contribution of chlorophyll fluorescence to the apparent vegetation reflectance. Sci Total Environ 404:433-439. doi:10.1016/j.scitotenv.2007.11.004

Cartelat A, Cerovic ZG, Goulas Y, Meyer S, Lelarge C, Prioul JL, Barbottin A, Jeuffroy MH, Gate P, Agati G, Moya I (2005) Optically assessed contents of leaf polyphenolics and chlorophyll as indicators of nitrogen deficiency in wheat (Triticum aestivum L.). Field Crops Res 91:35-49. doi:10.1016/j.fcr.2004.05.002

Cerovic ZG, Bergher M, Goulas Y, Tosti S, Moya I (1993) Simultaneous measurement of changes in red and blue fluorescence in illuminated isolated chloroplasts and leaf pieces: the contribution of NADPH to the blue fluorescence signal. Photosynth Res 36:193-204
Cerovic ZG, Morales F, Moya I (1994) Time-resolved spectral studies of blue-green fluorescence of leaves, mesophyll and chloroplasts of sugar beet (Beta vulgaris L.). Biochim Biophys Acta 1188:58 68. doi:10.1016/0005-2728(94)90022-1

Cerovic ZG, Goulas Y, Camenen L, Guyot G, Briantais JM, Morales F, Moya I (1995) Scaling fluorescence signals from the chloroplast to the canopy level. In: Guyot G (ed) Photosynthesis and remote sensing, Montpellier, France EARSel, Paris-Sud, Orsay, 220, pp $21-27$

Cerovic ZG, Langrand E, Latouche G, Morales F, Moya I (1998) Spectral characterization of $\mathrm{NAD}(\mathrm{P}) \mathrm{H}$ fluorescence in intact isolated chloroplasts and leaves: effect of chlorophyll concentration on reabsorption of blue-green fluorescence. Photosynth Res 56:291-301

Cerovic ZG, Samson G, Morales F, Tremblay N, Moya I (1999) Ultraviolet-induced fluorescence for plant monitoring: present state and prospects. Agronomie 19:543-578. doi:10.1051/ agro:19990701

Cerovic ZG, Ounis A, Cartelat A, Latouche G, Goulas Y, Meyer S, Moya I (2002) The use of chlorophyll fluorescence excitation spectra for the non-destructive in situ assessment of UVabsorbing compounds in leaves. Plant Cell Environ 25:16631676. doi:10.1046/j.1365-3040.2002.00942.x

Cerovic ZG, Cartelat A, Goulas Y, Meyer S (2005) In-the-field assessment of wheat-leaf polyphenolics using the new optical leaf-clip Dualex. In: Stafford JV (ed) Precision agriculture, 05. Wageningen Academic Publishers, Wageningen, pp 243250

Cerovic ZG, Goutouly JP, Hilbert G, Destrac-Irvine A, Martinon V, Moise N (2009) Mapping winegrape quality attributes using portable fluorescence-based sensors. In: Best S (ed) Progap INIA, FRUTIC 09, Conception, Chile, pp 301-310

Chaerle L, Leinonen I, Jones HG, van der Straeten D (2007) Monitoring and screening plant populations with combined thermal and chlorophyll fluorescence imaging. J Exp Bot 58:773-784. doi:10.1093/jxb/erl257

Chappelle EW, Williams DL (1987) Laser-induced fluorescence (LIF) from plant foliage. IEEE Trans Geosci Remote Sens 25(6):726736. doi:10.1109/TGRS.1987.289742

Chappelle EW, Wood FM Jr, McMurtrey JE III, Newcomb WW (1984) Laser-induced fluorescence of green plants. 1: A technique for the remote detection of plant stress and species differentiation. Appl Opt 23:134-138. doi:10.1364/AO.23.000134

Chappelle EW, McMurtrey JE III, Kim MS (1991) Identification of the pigment responsible for the blue fluorescence band in the laser induced fluorescence (LIF) spectra of green plants, and the potential use of this band in remotely estimating rates of photosynthesis. Remote Sens Environ 36:213-218. doi:10.1016/ 0034-4257(91)90058-E

Close DC, McArthur C, Hagerman AE, Davies NW, Beadle CL (2007) Phenolic acclimation to ultraviolet-A irradiation in Eucalyptus nitens seedlings raised across a nutrient environment gradient. Photosynthetica 45(1):36-42. doi:10.1007/s11099-007-0006-4

Cockell CS, Knowland J (1999) Ultraviolet radiation screening compounds. Biol Rev Camb Philos 74:311-345. doi:10.1111/ j.1469-185X.1999.tb00189.x

Colls JJ, Hall DP (2004) Application of a chlorophyll fluorescence sensor to detect chelate-induced metal stress in Zea mays. Photosynthetica 42(1):139-145

Corp LA, McMurtrey JE III, Chappelle EW, Daughtry CST, Kim MS, Mulchi CL (1998) Applications of fluorescence sensing systems to the remote assessment of nitrogen supply in field corn (Zea mays L.). Adv Laser Remote Sens Terrestrial Hydrogr Appl SPIE 3382:80-90. doi:10.1117/12.312631

Corp LA, Chappelle EW, McMurtrey III JE, Mulchi CL, Daughtry CST, Kim MS (2000) Advances in fluorescence sensing systems 
for the remote assessment of nitrogen supply in field corn. Geoscience and Remote Sensing Symposium, Proceedings. IGARSS 2000, IEEE

Corp LA, McMurtrey JE III, Middleton EM, Mulchi CL, Chappelle EW, Daughtry CST (2003) Fluorescence sensing systems: in vivo detection of biophysical variations in field corn due to nitrogen supply. Remote Sens Environ 86(4):470-479. doi:10.1016/ S0034-4257(03)00125-1

Cregg BM, Duck MW, Rios CM, Rowe DB, Koelling MR (2004) Chlorophyll fluorescence and needle chlorophyll concentration of Fir (Abies sp.) seedlings in response to $\mathrm{pH}$. Hortscience 39 (5):1121-1125

DaMatta FM, Loos RA, Silva EA, Loureiro ME (2002) Limitations to photosynthesis in Coffea canephora as a result of nitrogen and water availability. J Plant Physiol 159:975-981. doi:10.1078/ 0176-1617-00807

Debuisson S, Germain C, Garcia O, Panigai L, Moncomble D, Le Moigne M, Fadaili EM, Evain S, Cerovic ZG (2010) Using Multiplex ${ }^{\circledR}$ and Greenseeker ${ }^{\mathrm{TM}}$ to manage spatial variation of vine vigor in Champagne. 10th International Conference on Precision Agriculture. Denver, Colorado, July 18-21, 2010, CD-ROM, p 15

Demmig-Adams B, Björkman O (1987) Comparison of the effect of excessive light on chlorophyll fluorescence $(77 \mathrm{~K})$ and photon yield of $\mathrm{O}_{2}$ evolution in leaves of higher plants. Planta 171:171184

Demmig-Adams B, Adams WW III, Winter K, Meyer A, Schreiber U, Pereira JS, Krüger A, Czygan FC, Lange OL (1989) Photochemical efficiency of photosystem II, photon yield of $\mathrm{O}_{2}$ evolution, photosynthetic capacity, and carotenoid composition during the "midday depression" of net $\mathrm{CO}_{2}$ uptake in Arbutus unedo growing in Portugal. Planta 177:377-387

Dudelzak A, Babichenko SM, Poryvkina LV, Lapimaa J (1991) Laserinduced spectral signatures in investigations of sea upper layer. 5th International Colloquium-Physical Measurements and Signatures in Remote Sensing, Vol. ESA SP-319, Paris, Courchevel, France, pp 711-714

Esteban R, Olascoaga B, Becerril JM, García-Plazaola JI (2010) Insights into carotenoid dynamics in non-foliar photosynthetic tissues of avocado. Physiol Plantarum 140:69-78. doi:10.1111/ j.1399-3054.2010.01385.x

Ferguson RB, Hergert GW, Schepers JS, Gotway CA, Cahoon JE, Peterson TA (2002) Site-specific nitrogen management of irrigated maize: yield and soil residual nitrate effects. Soil Sci Soc Am J 66:544-553

Genty B, Briantais JM, Baker NR (1989) The relationship between the quantum yield of photosynthetic electron transport and quenching of chlorophyll fluorescence. Biochim Biophys Acta 990:87-92. doi:10.1016/S0304-4165(89)80016-9

Georgieva K, Szigeti Z, Sarvari E, Gaspar L, Maslenkova L, Peeva V, Peli E, Tuba Z (2007) Photosynthetic activity of homoiochlorophyllous desiccation tolerant plant Haberlea rhodopensis during dehydration and rehydration. Planta 225:955-964. doi:10.1007/s00425-006-0396-8

Gitelson AA, Buschmann C, Lichtenthaler HK (1998) Leaf chlorophyll fluorescence corrected for re-absorption by means of absorption and reflectance measurements. J Plant Physiol 152:283-296

Gitelson AA, Buschmann C, Lichtenthaler HK (1999) The chlorophyll fluorescence ratio F735/F700 as an accurate measurement of the chlorophyll content in plants. Remote Sens Environ 69 (3):296-302. doi:10.1016/S0034-4257(99)00023-1

Guidi L, Di Cagno R, Soldatini GF (2000) Screening of bean cultivars for their response to ozone as evaluated by visible symptoms and leaf chlorophyll fluorescence. Environ Pollut 107:349-355. doi:10.1016/S0269-7491(99)00170-0
Günther KP, Dahn HG, Lüdeker W (1994) Remote sensing vegetation status by laser-induced fluorescence. Remote Sens Environ 47:10-17. doi:10.1016/0034-4257(94)90122-8

Häder DP, Herrmann H, Schäfer J, Santas R (1997) Photosynthetic fluorescence induction and oxygen production in two Mediterranean Cladophora species measured on site. Aquat Bot 56:253-264. doi:10.1016/S0304-3770(96)01107-2

Hamilton J, Zangerl A, DeLucia E, Berenbaum M (2001) The carbonnutrient balance hypothesis: its rise and fall. Ecol Lett 4:86-95. doi:10.1046/j.1461-0248.2001.00192.x

Hashimoto M, Herai Y, Nagaoka T, Kouno K (2007) Nitrate leaching in granitic regosol as affected by $\mathrm{N}$ uptake and transpiration by corn. Soil Sci Plant Nutr 53(3):300-309. doi:10.1111/j.1747-0765.2007.00134.x

Hassan IA (2006) Effects of water stress and high temperature on gas exchange and chlorophyll fluorescence in Triticum aestivum L. Photosynthetica 44(2):312-315. doi:10.1007/s11099- 006-0024-7

Heege HJ, Reusch S, Thiessen E (2008) Prospects and results for optical systems for site-specific on-the-go control of nitrogentop-dressing in Germany. Precis Agric 9:115-131. doi:10.1007/ s11119-008-9055-3

Heisel F, Sowinska M, MiehéJ A, Lang M, Lichtenthaler HK (1996) Detection of nutrient deficiencies of maize by laser induced fluorescence imaging. J Plant Physiol 148:622-631

Heisel F, Sowinska M, Khalili E, Eckert C, Miehé J, Lichtenthaler HK (1997) Laser-induced fluorescence imaging for monitoring nitrogen fertilizing treatments of wheat. SPIE 3059:10-21. doi: $10.1117 / 12.277607$

Huang ZA, Jiang DA, Yang Y, Sun JW, Jin SH (2004) Effects of nitrogen deficiency on gas exchange, chlorophyll fluorescence, and antioxidant enzymes in leaves of rice plants. Photosynthetica 42(3):357-364. doi:10.1023/B:PHOT.0000046153.08935.4c

Hura T, Grzesiak S, Hura K, Grzesiak M, Rzepka A (2006) Differences in the physiological state between triticale and maize plants during drought stress and followed rehydration expressed by the leaf gas exchange and spectrofluorimetric methods. Acta Physiol Plant 28:433-443

Hura T, Grzesiak S, Hura K, Thiemt E, Tokarz K, Wedzony M (2007) Physiological and biochemical tools useful in drought-tolerance detection in genotypes of winter triticale: accumulation of ferulic acid correlates with drought tolerance. Ann Bot 100:767-775. doi:10.1093/aob/mcm162

Khamis S, Lamaze T, Lemoine Y, Foyer C (1990) Adaptation of the photosynthetic apparatus in maize leaves as a result of $\mathrm{N}$ limitation. Plant Physiol 94:1436-1443. doi:10.1093/aob/mci244

Kitajima M, Butler WL (1975) Quenching of chlorophyll fluorescence and primary photochemistry in chloroplasts by dibromothymoquinone. Biochim Biophys Acta 376(1):105-115. doi:10.1016/ 0005-2728(75)90209-1

Krause GH, Gallé A, Gademann R, Winter K (2003) Capacity of protection against ultraviolet radiation in sun and shade leaves of tropical forest plants. Funct Plant Biol 30:533-542. doi:10.1071/FP03047

Kruskopf M, Flynn KJ (2006) Chlorophyll content and fluorescence responses cannot be used to gauge reliably phytoplankton biomass, nutrient status or growth rate. New Phytol 169:525536. doi:10.1111/j.1469-8137.2005.01601.x

Lang M, Siffel P, Braunova Z, Lichtenthaler HK (1992) Investigations of the blue-green fluorescence emission of plant leaves. Bot Acta 105:435-440

Langsdorf G, Buschmann C, Sowinska M, Babani F, Mokry M, Timmermann F, Lichtenthaler HK (2000) Multicolour fluorescence imaging of sugar beet leaves with different nitrogen status by flash lamp UV-excitation. Photosynthetica 38(4):539-551

Lea US, Slimestad R, Smedvig P, Lillo C (2007) Nitrogen deficiency enhances expression of specific MYB and bHLH transcription factors and accumulation of end products in the flavonoid pathway. Planta 225:1245-1253. doi:10.1007/s00425-006-0414-x 
Lejealle S, Evain S, Cerovic ZG (2010) Multiplex: a new diagnostic tool for management of nitrogen fertilization of turfgrass. 10th International Conference on Precision Agriculture, Denver, Colorado, July 18-21, 2010, CD-ROM, p 15

Lenk S, Chaerle L, Pfündel EE, Langsdorf G, Hagenbeek D, Lichtenthaler HK, van der Straeten D, Buschmann C (2007) Multispectral fluorescence and reflectance imaging at the leaf level and its possible applications. J Exp Bot 58:807-814. doi:10.1093/jxb/erl207

Lichtenthaler HK (1996) Vegetation stress: an introduction to the stress concept in plants. J Plant Physiol 148:4-14

Lichtenthaler HK, Miehé JA (1997) Fluorescence imaging as a diagnostic tool for plant stress. Trends Plant Sci 2(8):316-320. doi:10.1016/S1360-1385(97)89954-2

Lichtenthaler HK, Schweiger J (1998) Cell wall bound ferulic acid, the major substance of the blue-green fluorescence emission of plants. J Plant Physiol 152:272-282

Lichtenthaler HK, Langdorf G, Lenk S, Buschmann C (2005) Chlorophyll fluorescence imaging of photosynthetic activity with the flash-lamp fluorescence imaging system. Photosynthetica 43 (3):355-369. doi:10.1007/s11099-005-0060-8

Lima JD, Mosquim PR, Da Matta FM (1999) Leaf gas exchange and chlorophyll fluorescence parameters in Phaseolus vulgaris as affected by nitrogen and phosphorus deficiency. Photosynthetica 37(1):113-121

Lu C, Zhang J (2000) Photosynthetic $\mathrm{CO}_{2}$ assimilation, chlorophyll fluorescence and photoinhibition as affected by nitrogen deficiency in maize plants. Plant Sci 151:135-143. doi:10.1016/ S0168-9452(99)00207-1

Maier SW, Günther KP (2001) Sun-induced fluorescence-a new tool for precision farming. Proceedings of the International Workshop on Spectroscopy Application in Precision Farming, FreisingWeihenstephan, Germany, January, 16th-18th, pp 90-93

Mauromicale G, Ierna A, Marchese M (2006) Chlorophyll fluorescence and chlorophyll content in field-grown potato as affected by nitrogen supply, genotype, and plant age. Photosynthetica 44 (1):76-82. doi:10.1007/s11099-005-0161-4

McMurtrey JE, Middleton EM, Corp LA, Campbell PKE, Butcher LM, Daughtry CST (2003) Optical reflectance and fluorescence for detecting nitrogen needs in Zea mays L. Geoscience and Remote Sensing Symposium, IGARSS'03. Proceedings, 2003 IEEE International, Volume 7, 21-25 July 2003, pp 4602-4604

Mercure SA, Daoust B, Samson G (2004) Causal relationship between growth inhibition, accumulation of phenolic metabolites, and changes of UV-induced fluorescences in nitrogen-deficient barley plants. Can J Bot 6:815-821. doi:10.1139/B04-062

Meroni M, Busetto L, Colombo R, Guanter L, Moreno J, Verhoef W (2010) Performance of spectral fitting methods for vegetation fluorescence quantification. Remote Sens Environ 114:363-374. doi:10.1016/j.rse.2009.09.010

Méthy M, Lacaze B, Olioso A (1991) Perspectives et limites de la fluorescence pour la télédétection de l'état hydrique d'un couvert végétal: cas d'une culture de soja. Int J Remote Sens 12(1):223230. doi:10.1080/01431169108929648

Méthy M, Olioso A, Trabaud L (1994) Chlorophyll fluorescence as a tool for management of plant resources. Remote Sens Environ 47:2-9. doi:10.1016/0034-4257(94)90121-X

Meyer S, Cartelat A, Moya I, Cerovic ZG (2003) UV-induced bluegreen and far-red fluorescence along wheat leaves: a potential signature of leaf ageing. J Exp Bot 54(383):757-769. doi:10.1093/jxb/erg063

Morales F, Cerovic ZG, Moya I (1994) Characterization of blue-green fluorescence in the mesophyll of sugar beet (Beta vulgaris L.) leaves affected by iron deficiency. Plant Physiol 106:127-133

Morales F, Cerovic ZG, Moya I (1998) Time-resolved blue-green fluorescence of sugar beet leaves. Temperature-induced changes and consequences for the potential use of blue-green fluorescence as a signature for remote sensing of plants. Aust J Plant Physiol 25:325-334. doi:10.1071/PP97085

Moshou D, Bravo C, Wahlen S, West J, McCartney A, De Baerdemaeker J, Ramon H (2006) Simultaneous identification of plant stresses and diseases in arable crops using proximal optical sensing and self-organising maps. Precis Agric 7:149164. doi:10.1007/s11119-006-9002-0

Moya I, Guyot G, Goulas Y (1992) Remotely sensed blue and red fluorescence emission for monitoring vegetation. ISPRS $\mathrm{J}$ Photogramm 47:205-231. doi:10.1016/0924-2716(92)90033-6

Norikane JH, Kurata K (2001) Water stress detection by monitoring fluorescence of plants under ambient light. T ASAE 44(6):19151922

Norikane J, Goto E, Kurata K, Takakura T (2003) A new relative referencing method for crop monitoring using chlorophyll fluorescence. Adv Space Res 31:245-248. doi:10.1016/S0273-1177(02) 00746-9

Nybakken L, Bilger W, Johanson U, Björn LO, Zielke M, Solheim B (2004) Epidermal UV-screening in vascular plants from Svalbard (Norwegian Arctic). Polar Biol 27:383-390. doi:10.1007/s00300-004-0602-8

Ounis A, Cerovic ZG, Briantais JM, Moya I (2001) Dual-excitation FLIDAR for the estimation of epidermal UV absorption in leaves and canopies. Remote Sens Environ 76:33-48. doi:10.1016/ S0034-4257(00)00190-5

Pfündel EE, Ben Ghozlen N, Meyer S, Cerovic ZG (2007) Investigating UV screening in leaves by two different types of portable UV fluorimeters reveals in vivo screening by anthocyanins and carotenoids. Photosynth Res 93:205-221. doi:10.1007/s11120-007-9135-7

Porra RJ, Thompson WA, Kreidemann PE (1989) Determination of accurate extinction coefficients and simultaneous equations for assaying chlorophyll $a$ and $b$ extracted with four different solvents: verification of the concentration of chlorophyll standards by atomic absorption spectroscopy. Biochim Biophys Acta 975:384-394. doi:10.1016/S0005-2728(89)80347-0

Poryvkina L, Babichenko S, Leeben A (1997) Spectral fluorescent signatures (SFS) in characterisation of water environment. In: Babichenko S, Reuter R (eds) 3rd EARSeL Workshop on Lidar Remote Sensing of Land and Sea, Tallinn, Estonia, pp 140-144

Richards JT, Schuerger AC, Capelle G, Guikema JA (2003) Laserinduced fluorescence spectroscopy of dark- and light-adapted bean (Phaseolus vulgaris L.) and wheat (Triticum aestivum L.) plants grown under three irradiance levels and subjected to fluctuating lighting conditions. Remote Sens Environ 84:323341. doi:10.1016/S0034-4257(02)00115-3

Robberecht R, Caldwell MM (1978) Leaf epidermal transmittance of ultraviolet radiation and its implications for plant sensitivity to ulraviolet-radiation induced injury. Oecologia 32(3):277-287

Rodríguez-Román A, Iglesias-Prieto R (2005) Regulation of photochemical activity in cultured symbiotic dinoflagellates under nitrate limitation and deprivation. Mar Biol 46:1063-1073. doi:10.1007/s00227-004-1529-x

Rouse JW Jr, Haas RH, Schell JA, Deering DW (1973) Monitoring vegetation systems in the Great Plains with ERTS. Third ERTS Symposium, Vol. 1. Washington, DC, NASA SP-351, pp 309317

Samborski SM, Tremblay N, Fallon E (2009) Strategies to make use of plant sensors-based diagnostic information for nitrogen recommendations. Agron J 101:800-816. doi:10.2134/agronj2008. 0162Rx

Samson G, Tremblay N, Dudelzak AE, Babichenko SM, Dextraze L, Wollring J (2000) Nutrient stress of corn plants: early detection and discrimination using a compact multiwavelength fluorescent lidar. 4th EARSeL Workshop Lidar Remote Sensing of Land and Sea held during the 20th EARSeL Symposium, Dresden, 14-16 
June 2000. http://las.physik.uni-oldenburg.de/projekte/earsel/ 4th_workshop.html

Schächtl J, Huber G, Maidl FX, Sticksel E, Schulz J, Haschberger P (2005) Laser-induced chlorophyll fluorescence measurements for detecting the nitrogen status of wheat (Triticum aestivum L.) canopies. Precis Agric 6:143-156. doi:10.1007/s11119-0041031-y

Schreiber U, Bilger W (1993) Progress in chlorophyll fluorescence research: major developments during the past years in retrospect. In: Liittge U, Ziegler H (eds) Progress in botany, vol 54. Springer, Berlin, pp 151-153

Schreiber U, Bilger W, Neubauer C (1994) Chlorophyll fluorescence as a nonintrusive indicator for rapid assessment of in vivo photosynthesis. In: Schulze ED, Caldwell MM (eds) Ecophysiology of photosynthesis. Ecological studies, vol 100. Springer, Berlin, pp 49-70

Schweiger J, Lang M, Lichtenthaler HK (1996) Differences in fluorescence excitation spectra of leaves between stressed and non-stressed plant. J Plant Physiol 148:536-547

Shelly K, Higgins T, Beardall J, Wood B, McNaughton D, Heraud P (2007) Characterising nutrient-induced fluorescence transients (NIFTs) in nitrogen-stressed Chlorella emersonii (Chlorophyta). Phycologia 46:503-512. doi:10.2216/06-55.1

Stober F, Lang M, Lichtenthaler HK (1994) Studies on the blue, green, and red fluorescence emission signatures of green, etiolated, and white leaves. Remote Sens Environ 47:65-71. doi:10.1016/0034-4257(94)90129-5

Subhash N, Wenzel O, Lichtenthaler HK (1999) Changes in bluegreen and chlorophyll fluorescence emission and fluorescence ratios during senescence of tobacco plants. Remote Sens Environ 69:215-223. doi:10.1016/S0034-4257(99)00029-2

Takeuchi A, Saito Y, Kanoh M, Kawahara TD, Nomura A, Ishizawa H, Matsuzawa T, Komatsu K (2002) Laser-induced fluorescence detection of plant and optimal harvest time of agricultural products (lettuce). Am Soc Agric Eng 18(3):361-366

Tartachnyk I, Rademacher I (2003) Estimation of nitrogen deficiency of sugar beet and wheat using parameters of laser induced and pulse amplitude modulated chlorophyll fluorescence. J Appl Botany-Angewandte Botanik 77:61-67

Tartachnyk I, Rademacher I, Kuhbauch W (2006) Distinguishing nitrogen deficiency and fungal infection of winter wheat by laserinduced fluorescence. Precis Agric 7:281-293

Tartachnyk I, Blanke MM, Jackson MB (2007) Effect of hail on photosynthesis, chlorophyll fluorescence, stomatal closure and evapotranspiration of apple leaves. Acta Hortic 732:543-547
Thoren D, Schmidhalter U (2009) Nitrogen status and biomass determination of oilseed rape by laser-induced chlorophyll fluorescence. Eur J Agron 30:238-242. doi:10.1016/j. eja.2008.12.001

Thoren D, Thoren P, Schmidhalter U (2010) Influence of ambient light and temperature on laser-induced chlorophyll fluorescence measurements. Eur J Agron 32:169-176. doi:10.1016/j. eja.2009.10.003

Tremblay N (2004) Determining nitrogen requirements from crops characteristics. Benefits and challenges. Recent Research Development in Agronomy \& Horticulture 1. Chapter 9, pp 157-182

Tremblay N, Wang Z, Bélec C (2007) Evaluation of the Dualex for the assessment of corn nitrogen status. J Plant Nutr 30:1355-1369. doi:10.1080/01904160701555689

Tremblay N, Wang Z, Bélec C (2010) Performance of Dualex in spring wheat for crop nitrogen status assessment, yield prediction and estimation of soil nitrate content. J Palnt Nutr 33(1):57-70. doi:10.1080/01904160903391081

Valentini R, Cecchi G, Mazzinghi P, Mugnozza GS, Agati G, Bazzani M, De Angelis P, Fusi F, Matteucci G, Raimondi V (1994) Remote sensing of chlorophyll a fluorescence of vegetation canopies: 2. Physiological significance of fluorescence signal in response to environmental stresses. Remote Sens Environ 47:29 35. doi:10.1016/0034-4257(94)90124-4

Wagner H, Gilbert M, Wilhelm C (2003) Longitudinal leaf gradients of UV-absorbing screening pigments in barley (Hordeum vulgare). Physiol Plant 117:383-391. doi:10.1034/j.13993054.2003.00045.x

Xu ZZ, Zhou GS, Wang YL, Han GX, Li YJ (2008) Changes in chlorophyll fluorescence in maize plants with imposed rapid dehydration at different leaf ages. J Plant Growth Regul 27:8392. doi:10.1007/s00344-007-9035-2

Zarco-Tejada PJ, Miller JR, Mohammed GH, Noland TL, Sampson PH (2002) Vegetation stress detection through chlorophyll $a+b$ estimation and fluorescence effects on hyperspectral imagery. J Environ Qual 31:1433-1441. doi:10.2134/jeq2002.1433

Zarco-Tejada PJ, Berni JAJ, Suarez L, Sepulcre-Cantó G, Morales F, Miller JR (2009) Imaging chlorophyll fluorescence with an airborne narrow-band multispectral camera for vegetation stress detection. Remote Sens Environ 113:1262-1275. doi:10.1016/j. rse.2009.02.016

Zhang YP, Tremblay N (2010) Evaluation of the Multiplex ${ }^{\circledR}$ fluorescence sensor for the assessment of corn nitrogen status. 10th International Conference on Precision Agriculture, Denver, Colorado, July 18 21, 2010, CD-ROM, p 9 